\title{
セントポーリア（Saintpaulia）花弁に蓄積する黄色色素の同定
}

\author{
出口亜由美 ${ }^{1,2}$ ・ 大野 $\quad$ 翔 $^{1}$ ・立澤文見 ${ }^{3}$ ・ 土井元章 ${ }^{1}$ ・細川宗孝 ${ }^{1} *$ \\ ${ }^{1}$ 京都大学大学院農学研究科 606-8502 京都府京都市左京区北白川追分町 \\ 2 日本学術振興会特別研究員 (DC2) \\ 3 岩手大学農学部 $020-8550$ 岩手県盛岡市上田
}

\section{Identification of the Yellow Pigment in Saintpaulia Flowers}

\author{
Ayumi Deguchi ${ }^{1,2}$, Sho Ohno ${ }^{1}$, Fumi Tatsuzawa ${ }^{3}$, Motoaki Doi ${ }^{1}$ and Munetaka Hosokawa ${ }^{1 *}$ \\ ${ }^{I}$ Graduate School of Agriculture, Kyoto University, Sakyo-ku, Kyoto 606-8502, Japan \\ ${ }^{2}$ Research fellow of Japan Society for the Promotion of Science \\ ${ }^{3}$ Faculty of Agriculture, Iwate University, Morioka 020-8550, Japan
}

\begin{abstract}
A yellow flavonoid pigment was isolated from Saintpaulia 'Tomorrow's Snowy Night' with pale yellow pigmentation at the petal base. The pigment, chalcononaringenin 2',4'-diglucoside, was identified using chemical and spectroscopic methods. The amount of this pigment in somaclonal mutants from 'Tomorrow's Snowy Night' whose petals looked yellow visually was eighttimes higher than that in the mother plant, confirming that the accumulated yellow pigment in Saintpaulia petals was chalcononaringenin 2',4'-diglucoside. Moreover, this yellow pigment also accumulated in the stamen filaments, and it was detected in the stamen filaments but not in the petals of the pink cultivar 'Thamires'. This suggests that the yellow pigment generally accumulates in the stamen filaments of Saintpaulia and that most cultivars have the capability to biosynthesize this yellow pigment regardless of their flower colors. These results may be useful to reveal the genetic mechanism for chalcononaringenin 2', $4^{\prime}$-diglucoside biosynthesis.
\end{abstract}

Key Words : glucose, NMR, somaclonal variation

キーワード：グルコース，NMR，組織培養変異

\section{緒言}

セントポーリア（Saintpaulia sp.）は南アフリカ原産の多 年草で，鉢花として最も人気のある花卉園芸作物の一つで ある. 花色は白, ピンク, 赤, 紫および青紫があり, それ らの花色を形成するフラボノイド色素はこれまでに同定さ れている (Griesbach, 1998; Harborne, 1966; Khokhar ら， 1982; Tatsuzawa 5, 2012, 2015; Tatsuzawa • Hosokawa, 2016). 七 ントポーリアには濃黄色色素のカルコンやオーロン, カロ テノイドは蓄積されず，アジサイなどと同様に花弁全体が 濃い黄色の品種は存在しないが, 花弁の一部のみが黄色を 呈する品種が, 現在黄色セントポーリアとして流通してい る.しかしながら, この黄色セントポーリアに蓄積する黄 色色素はまだ同定されていない。我々は花弁の基部が薄く 黄色に着色する ‘Tomorrow's Snowy Night' において組織 培養により花弁の大部分が薄く黄色を呈する変異個体を得 た. 本研究では, この ‘Tomorrow’s Snowy Night’ の黄色

2015 年 7 月 13 日 受付. 2015 年 9 月 14 日 受理.

* Corresponding author. E-mail: mune@kais.kyoto-u.ac.jp
変異体の解析からセントポーリアに蓄積する黄色色素を特 定し，構造を決定した。

\section{材料および方法}

\section{1. 供試材料}

セントポーリア ‘Tomorrow’s Snowy Night’を用いた. 栽培は寒冷紗で $10000 \mathrm{~lx}$ 以下に調節した最低気温 $12^{\circ} \mathrm{C}$ の 京都大学のガラスハウスで行った. 黄色色素の構造決定の ために乾燥花弁約 $20 \mathrm{~g}$ を用意した。 また，HPLC 分析に は 'Tomorrow’s Snowy Night’の親個体（第 1 図A），後述 の組織培養により生じた「黄色変異体」(第 1 図 B), 拈よ びピンク地に青斑の入った‘タミレス’（第 1 図C）の花 弁拉よび花系を供試した.

\section{2. 組織培養変異体の獲得}

‘Tomorrow’s Snowy Night’ の完全展開葉を有効塩素濃度 $0.5 \%$ の次亜塩素酸ナトリウム溶液で 10 分間殺菌し, 滅菌 水でよくすすいだ. 主脈を含むよらに $1 \mathrm{~cm}$ 角で切り取っ た葉片あるいは葯を外植体とし，1-Naphthaleneacetic acid （NAA） $0.1 \mathrm{ppm,} \mathrm{Benzyl} \mathrm{adenine（BA）} 0.5 \mathrm{ppm}$ を含も MS 培地（Murashige・Skoog, 1962）に置床した。培養は白色蛍 


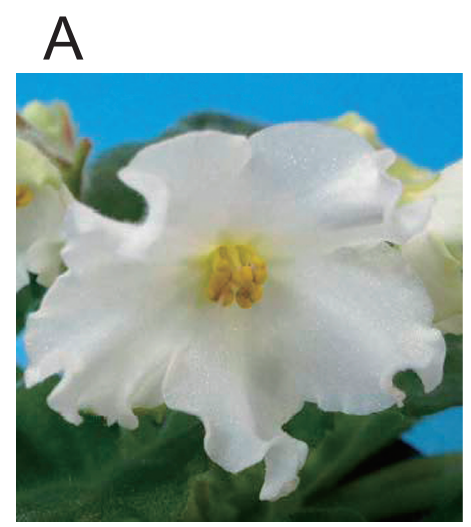

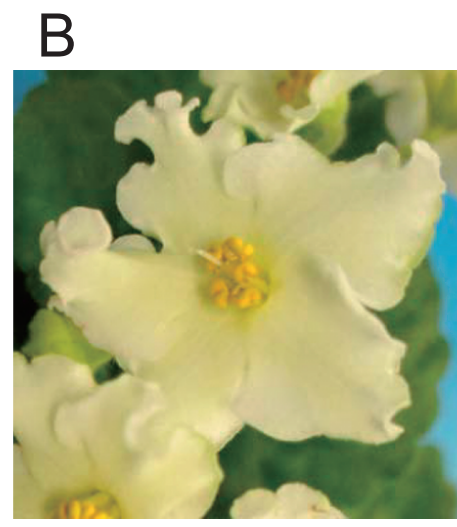

第 1 図 供試したセントポーリア

A : 'Tomorrow's Snowy Night' 親個体

B : 'Tomorrow's Snowy Night' 黄色変異体 $\mathrm{C}:$ 'タミレス’

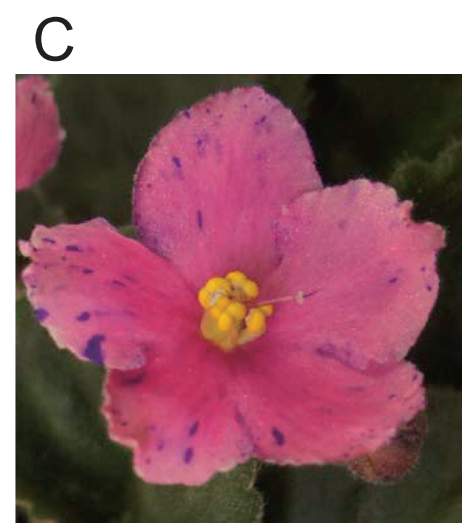

光灯で $3000 \mathrm{~lx} ， 16$ 時間日長， $25^{\circ} \mathrm{C}$ の条件下で行った. 発 生した不定芽を寒冷紗で 10000 lx 飞調節した最低気温 $12^{\circ} \mathrm{C}$ のガラスハウス内で育成した，培地はバーミキュラ イト：パーライト：ピートモス $=2: 2: 1(\mathrm{v} / \mathrm{v} / \mathrm{v})$ で混合 した混合培地を用いた。 適宜, 液体肥料（花工場，住友化 学園芸（株）を与えて開花させた。変異は目視で確認し, 開花してすぐに花弁の大部分が黄色を呈する「黄色変異体」 を HPLC 解析に用いた.

\section{3. ‘Tomorrow's Snowy Night' 花弁に蓄積する黄色色素 の精製}

“Tomorrow's Snowy Night' 親個体の乾燥花弁約 $20 \mathrm{~g}$ を $2 \mathrm{~L}$ のメタノールに 24 時間浸漬し, 抽出液をろ紙でろ過 した。 ダイヤイオン HP-20（(株）三菱化学）抒よびセファ デックス LH-20（GEへルスケア・ジャパン（株））カラム クロマトグラフィーの後, BAW（ $n$-ブタノール：酢酸： 水 $=4: 1: 2, \mathrm{v} / \mathrm{v} / \mathrm{v})$ を展開溶媒とするぺーパークロマト グラフィー（ADVANTEC）により黄色色素を精製した. 精製された色素を調べるために HPLC 分析を行った。分 析は Tatsuzawa ら (2012) と同様に, C18 カラム (Spherisorb ODS2 Column $4.6 \phi \times 250 \mathrm{~mm}$, Waters）を装着した LC-10A HPLC システム（(株）島津製作所）用いて， $40^{\circ} \mathrm{C}$, 流速 $1 \mathrm{~mL} \cdot \mathrm{min}^{-1}$, 検出波長 $350 \mathrm{~nm}$ で行った。溶出液として A 液（1.5\% リン酸水溶液）打よび B 液（1.5\% リン酸， $20 \%$ 酢酸，25\%アセトニトリル水溶液）を用意し，サンプル注 入後 40 分間でB 液の割合が $20 \%$ から $85 \%$ 亿，続く 5 分 間で再び 20\%になるよらに濃度勾配を設定した。

\section{4. 黄色色素の化学分析}

精製した色素の吸収スペクトルは分光光度計（MPS2450，（株）島津製作所）を用いて測定した。溶媒には，

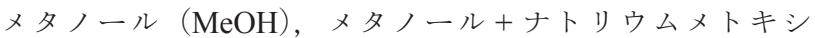

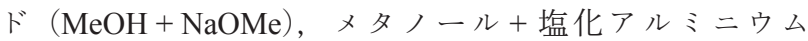
$\left(\mathrm{MeOH}+\mathrm{AlCl}_{3}\right)$, メタノール+塩化アルミニウム +塩酸 $\left(\mathrm{MeOH}+\mathrm{AlCl}_{3}+\mathrm{HCl}\right)$, メ夕ノール+酢酸ナトリウム $(\mathrm{MeOH}+\mathrm{NaOAc})$ 抢よびメタノール+酢酸ナトリウ
ム + ホウ酸 $\left(\mathrm{MeOH}+\mathrm{NaOAc}+\mathrm{H}_{3} \mathrm{BO}_{3}\right)$ の 6 種類を用いた. 精製した色素 $0.5 \mathrm{mg}$ を $1 \mathrm{~mL}$ の $2 \mathrm{~N}$ 塩酸に溶解させ，沸 騰浴中で 2 時間処理することで加水分解した。 サンプルを 冷却した後， $5 \mathrm{~mL}$ のエタノールを加えてエバポレーター で濃縮した。精製色素の糖を薄層（七ルロース薄層板， $20 \times 20 \mathrm{~cm}$, Merck）クロマトグラフィー（TLC）により分 析した。 糖の分析にはBAW と ETN（エタノール：アンモ ニア: 水 $=16: 1: 3$ ) を展開溶媒として用い（Tatsuzawa ら, 2015)，標品との比較により同定した．糖はAHP（1.66 g の o- フタル酸と $0.91 \mathrm{~mL}$ のアニリンを水で飽和した $n$-ブ タノールで $10 \mathrm{~mL}$ とした)を噴霧して発色させた (Harborne, 1984）。また，加水分解処理の開始後 1 分後の色素溶液を部 分加水分解物として用い，アサガオ (Ipomoea nil (L.) Roth.) の chalcononaringenin 2'-glucoside とともに HPLC 分析した.

\section{5. 黄色色素の構造決定}

精製した黄色色素 $1 \mathrm{mg}$ を High resolution fast atom bombardment mass spectra（HR-FABMS）（JEOL JMS-700，日本 電子（株））により分析し，分子量を決定した。さらに精製 黄色色素 $5 \mathrm{mg}$ 存 $\mathrm{CD}_{3} \mathrm{OD}$ に溶かし, NMR（JEOL AL-400, 日本電子 (株) ) の測定 $\left[{ }^{1} \mathrm{H}(400 \mathrm{MHz}),{ }^{13} \mathrm{C}(100 \mathrm{MHz})\right.$, ${ }^{1} \mathrm{H}-{ }^{1} \mathrm{H}$ COSY (correlation spectroscopy), ${ }^{1} \mathrm{H}-{ }^{1} \mathrm{H}$ NOESY (nuclear Overhauser enhancement and exchange spectroscopy), ${ }^{1} \mathrm{H}-{ }^{13} \mathrm{C}$ HMQC (heteronuclear multiple quantum correlation)，㧊よび ${ }^{1} \mathrm{H}-{ }^{13} \mathrm{C}$ HMBC (heteronuclear multiple bond coherence)] を行 い, 測定後に色素を回収し, さらに乾燥後, DMSO- $d_{6}$ に 溶かし再度 NMR の測定を行い, 構造解析を行った。

\section{6. 花弁および花糸抽出液の HPLC 分析}

'Tomorrow's Snowy Night' 親個体, 黄色変異体预よび '夕 ミレス’の生花弁を液体窒素中で磨砕し, 生花弁 $100 \mathrm{mg}$ 当たり $1 \mathrm{~mL}$ の\%酢酸水を加光た．遠心分離により残渣 を取り除き，HPLC 分析に供試した。分析は Deguchi ら （2015）と同様に, C18 カラム（Spherisorb ODS2 Column 4.6 $\phi \times 250 \mathrm{~mm}$ ）を装着した L-7000 シリーズ HPLC システム （(株）日立製作所）を用いて， $40^{\circ} \mathrm{C}$ ，流速 $1 \mathrm{~mL} \cdot \mathrm{min}^{-1}$, 
検出波長 $350 \mathrm{~nm}$ で行った. 溶出液の組成拈よび濃度勾配 は先述のと打りとした。 また，花糸からの色素抽出は $10 \mathrm{mg}$ 当たり $1 \mathrm{~mL}$ の\%酢酸水で行い, 同様に HPLC 分 析を行った. HPLCデータの全ピーク面積および黄色色素 のピーク面積について, ‘Tomorrow's Snowy Night' の親個 体を基準とした時の相対值を算出した.

\section{結 果}

\section{1. 黄色色素の精製}

‘Tomorrow’s Snowy Night’ 親個体の花弁抽出液の HPLC 分析の結果, 十数本のピークが確認できた（第 2 図 A). 305 個体の組織培養個体中で得られた 2 個体の黄色変異体 と親個体とで HPLCのピークを比較すると, ピークの種 類に違いはなかったものの，保持時間（Rt） $18.8 \mathrm{~min}$ 付近

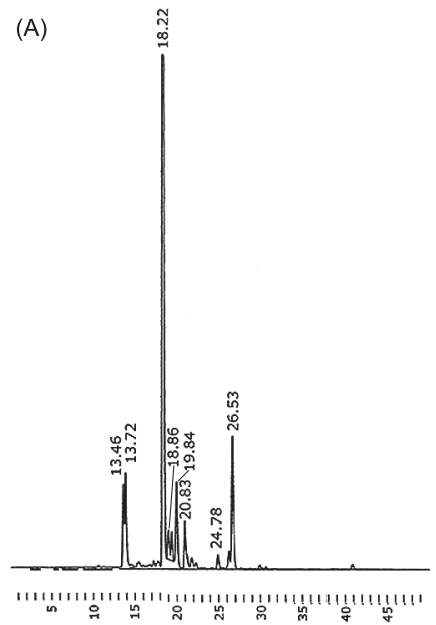

のピークに顕著な差があり，いずれの黄色変異体でもこの ピークが高かった（第 2 図 B）。親個体の乾燥花弁から黄 色色素を分離精製し， HPLC 分析を行った結果，親個体と 黄色変異体とで顕著に差のあった Rt 18.8 min 付近のピー クのみが検出された。これらの結果から，このピークがセ ントポーリアの黄色発現の原因となるピークであると考 穴, 乾燥花弁 $20 \mathrm{~g}$ から精製された $7 \mathrm{mg}$ の色素を続く解析 に使用した。

\section{2. 黄色色素の化学分析}

加水分解の結果，精製された黄色色素からはグルコース が検出された。部分加水分解物の HPLC 分析の結果，新

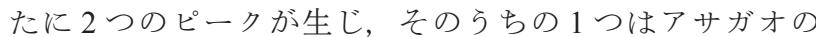
chalcononaringenin $2^{\prime}$-glucoside のピークと一致した. 6 種類の溶媒での吸収スペクトルは以下のと拈りであっ

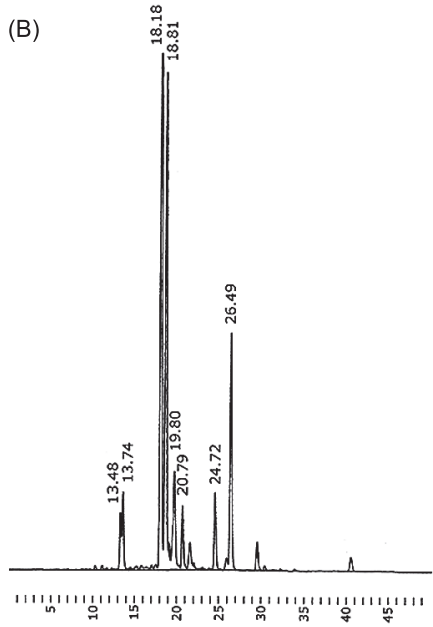

第 2 図 ‘Tomorrow’s Snowy Night’ 親個体（A）执よび黄色変異体（B）の花弁抽出液のクロマトグラム（350 nm） 数字は保持時間を示す

18.22 （A）㧊よび 18.18 （B）のピーク（同一ピーク）は検出上限を超えていた

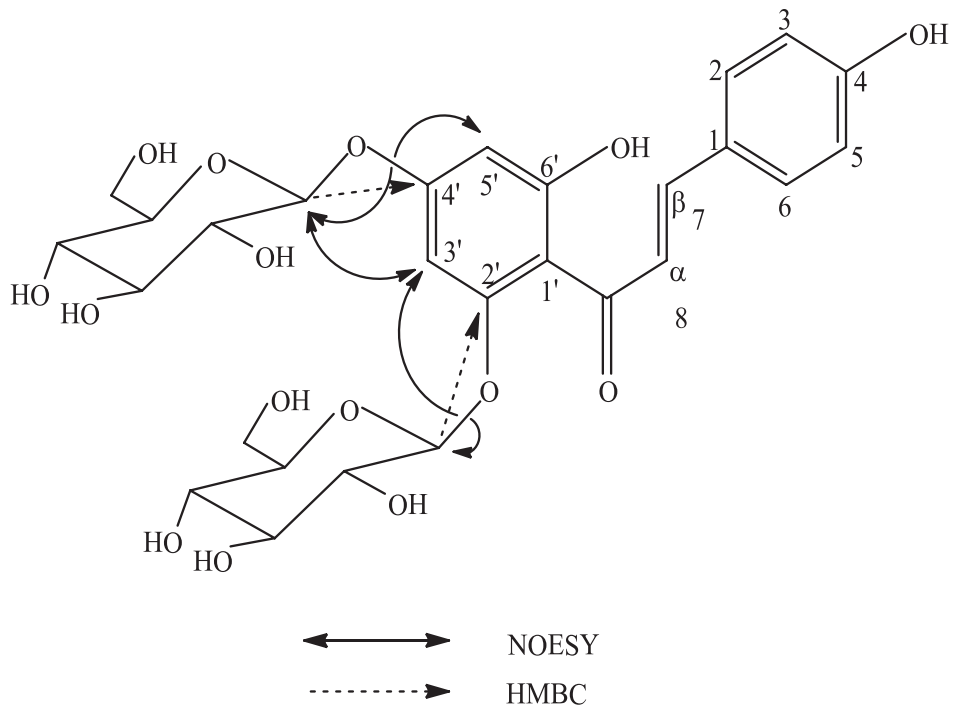

第 3 図 セントポーリアの黄色色素 chalcononaringenin 2',4'-diglucoside の構造 NOESY : nuclear Overhauser enhancement and exchange spectroscopy $\mathrm{HMBC}$ : heteronuclear multiple bond coherence 
た. UV : $\lambda_{\max }(\mathrm{nm}) \mathrm{MeOH} 368,305 \mathrm{sh}, 243 \mathrm{sh} ; \mathrm{MeOH}+\mathrm{NaOMe}$ $435 \mathrm{sh}, 369,314 \mathrm{sh}, 243 \mathrm{sh} ; \mathrm{MeOH}+\mathrm{AlCl}_{3} 421,324,252 \mathrm{sh}$; $\mathrm{MeOH}+\mathrm{AlCl}_{3}+\mathrm{HCl} 421 \mathrm{sh}, 388,319,254 \mathrm{sh} ; \mathrm{MeOH}+\mathrm{NaOAc}$ $368,305 \mathrm{sh}, 243 \mathrm{sh} ; \mathrm{MeOH}+\mathrm{NaOAc}+\mathrm{H}_{3} \mathrm{BO}_{3} 368,305 \mathrm{sh}, 243 \mathrm{sh}$.

\section{3. 黄色色素の構造決定}

HR-FABMS により $\mathrm{m} / \mathrm{z} 597.1823[\mathrm{M}+\mathrm{H}]^{+}$が得られ, 分子 式 $\mathrm{C}_{27} \mathrm{H}_{33} \mathrm{O}_{15}$ （597.1819） と判定した. この結果はカルコ ノナリンゲニン 1 分子およびグルコース 2 分子に相当した. また，NMRの測定結果から各分子に相当するシグナル が検出され，さらにそれらの結合様式も ${ }^{1} \mathrm{H}-{ }^{1} \mathrm{H}$ NOESY, ${ }^{1} \mathrm{H}-{ }^{13} \mathrm{C} \mathrm{HMBC}$ により決定された（第 3 図）。DMSO- $d_{6}$ 打よ び $\mathrm{CD}_{3} \mathrm{OD}$ での NMR スペクトルデータ $\left[{ }^{1} \mathrm{H}(400 \mathrm{MHz})\right.$, $\left.{ }^{13} \mathrm{C}(100 \mathrm{MHz})\right]$ を以下に示す.

DMSO- $d_{6}{ }^{1} \mathrm{H}$ NMR; chalcononaringenin: $7.65(d J=8.6 \mathrm{~Hz}$, $\mathrm{H}-2), 6.83(d J=8.6 \mathrm{~Hz}, \mathrm{H}-3), 6.83(d J=8.6 \mathrm{~Hz}, \mathrm{H}-5), 7.65$ $(d J=8.6 \mathrm{~Hz}, \mathrm{H}-6), 7.88(d J=15.9 \mathrm{~Hz}, \mathrm{H}-7(\alpha)), 7.63(d J=$ $15.9 \mathrm{~Hz}, \mathrm{H}-8(\beta)), 6.37$ ( $d J=2.0 \mathrm{~Hz}, \mathrm{H}-3$ '), $6.21(d J=2.0 \mathrm{~Hz}$, H-5'); glucose(2'): $5.13(d J=7.1 \mathrm{~Hz}, \mathrm{H}-1), 3.33(t J=8.6 \mathrm{~Hz}$, H-2), 3.29 ( $m, \mathrm{H}-3), 3.15^{\mathrm{a}}(m, \mathrm{H}-4), 3.45^{\mathrm{b}}(m, \mathrm{H}-5), 3.51^{\mathrm{c}}(m$, H-6a), $3.73^{\mathrm{d}}$ ( $\left.m, \mathrm{H}-6 \mathrm{~b}\right)$; glucose(4'): 4.99 ( $\left.d J=7.3 \mathrm{~Hz}, \mathrm{H}-1\right)$, $3.26(t J=8.3 \mathrm{~Hz}, \mathrm{H}-2), 3.24(m, \mathrm{H}-3), 3.18^{\mathrm{a}}(m, \mathrm{H}-4), 3.47^{\mathrm{b}}(m$, H-5), $3.49^{\mathrm{c}}$ ( $\left.m, \mathrm{H}-6 \mathrm{a}\right), 3.68^{\mathrm{d}}$ ( $\left.m, \mathrm{H}-6 \mathrm{~b}\right) ;{ }^{13} \mathrm{C}$ NMR; chalcononaringenin: 125.9 (C-1), 130.9 (C-2), 115.9 (C-3), 160.0 (C-4), 115.9 (C-5), 130.9 (C-6), 123.9 (C-7( $\alpha)$ ), 143.7 (C-8( $\beta)), 192.6$ (C-9(CO)), 107.4 (C-1'), 159.2 (C-2'), 94.5 (C-3'), 162.5 (C-4'), 97.5 (C-5'), 164.3 (C-6'); glucose(2'): 100.1 (C-1), 73.5 (C-2), $76.3(\mathrm{C}-3), 69.6^{\mathrm{e}}(\mathrm{C}-4), 77.0^{\mathrm{f}}(\mathrm{C}-5), 60.6^{\mathrm{g}}(\mathrm{C}-6)$; glucose $\left(4^{\prime}\right)$ : 99.2 (C-1), $72.9(\mathrm{C}-2), 76.6(\mathrm{C}-3), 69.7^{\mathrm{e}}(\mathrm{C}-4), 77.2^{\mathrm{f}}(\mathrm{C}-5), 60.6^{\mathrm{g}}$ (C-6). ${ }^{\mathrm{a}-\mathrm{g}}$ は入れ替わり得る.

$\mathrm{CD}_{3} \mathrm{OD}{ }^{1} \mathrm{H} \mathrm{NMR}$; chalcononaringenin: $7.62(d J=8.5 \mathrm{~Hz}$, $\mathrm{H}-2), 6.84(d J=8.5 \mathrm{~Hz}, \mathrm{H}-3), 6.84(d J=8.5 \mathrm{~Hz}, \mathrm{H}-5), 7.62$ $(d J=8.5 \mathrm{~Hz}, \mathrm{H}-6), 7.97(d J=15.4 \mathrm{~Hz}, \mathrm{H}-7(\alpha)), 7.71(d J=$ $15.4 \mathrm{~Hz}, \mathrm{H}-8(\beta)), 6.51(d J=2.4 \mathrm{~Hz}, \mathrm{H}-3$ '), 6.28 ( $d J=2.4 \mathrm{~Hz}$, H-5'); glucose(2'): $5.20(d J=7.3 \mathrm{~Hz}, \mathrm{H}-1), 3.53(t J=8.7 \mathrm{~Hz}$, $\mathrm{H}-2), 3.51(m, \mathrm{H}-3), 3.36^{\mathrm{a}}(t J=9.0 \mathrm{~Hz}, \mathrm{H}-4), 3.66^{\mathrm{b}}(m, \mathrm{H}-5)$, 3.60-3.80 (H-6a), 3.80-4.00 (H-6b); glucose(4'): 5.04 (d $J=$ $7.1 \mathrm{~Hz}, \mathrm{H}-1), 3.47$ ( $m, \mathrm{H}-2), 3.45$ ( $m, \mathrm{H}-3), 3.33^{\mathrm{a}}$ ( $t J=9.3 \mathrm{~Hz}$, $\mathrm{H}-4), 3.77^{\mathrm{b}}$ (m, H-5), 3.60-3.80 (H-6a), 3.80-4.00 (H-6b); ${ }^{13} \mathrm{C}$ NMR; chalcononaringenin: 128.4 (C-1), 132.0 (C-2), 117.0 (C-3), 161.4 (C-4), 117.0 (C-5), 132.0 (C-6), 125.7 (C-7( $\alpha)$ ),
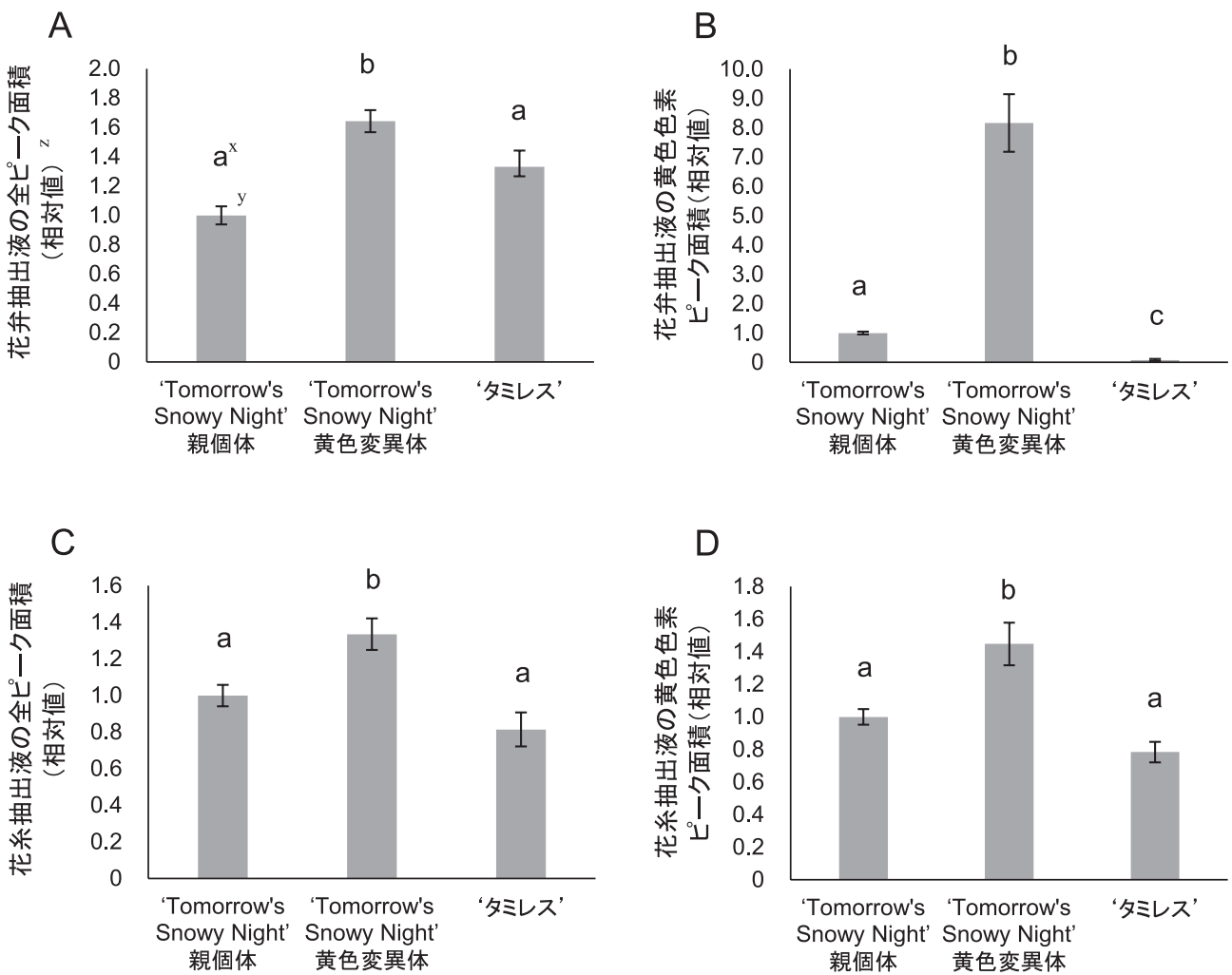

第 4 図花弁および花系抽出液の HPLC ピーク面積の比較

$\mathrm{A}$ : 花弁抽出液の全ピーク面積の相対値

B : 花弁抽出液の黄色色素 chalcononaringenin $2^{\prime}, 4^{\prime}$-diglucoside ピーク面積の相対值

$\mathrm{C}:$ 花糸抽出液の全ピーク面積の相対値

D : 花系抽出液の黄色色素 chalcononaringenin $2^{\prime}, 4^{\prime}$-diglucoside ピーク面積の相対值

zすべて ‘Tomorrow’s Snowy Night'の親個体を1とした

${ }^{y} n=4$ バーは標準誤差を示す

${ }^{\mathrm{x}}$ Tukey の多重検定により異なる英文字（a-c）間に有意差（5\%）があることを示す 
145.2 (C-8( $\beta)), 195.0$ (C-9(CO)), 109.3 (C-1'), 161.2 (C-2'), 95.8 (C-3'), 164.5 (C-4'), 99.7 (C-5'), 166.5 (C-6’); glucose(2'): 101.7 (C-1), 75.0 (C-2), 78.4 (C-3), $71.6^{\mathrm{c}}$ (C-4), 78.5 (C-5), $62.7^{\mathrm{e}}$ (C-6); glucose(4'): 101.2 (C-1), 74.7 (C-2), 77.9 (C-3), $71.6^{\mathrm{c}}(\mathrm{C}-4), 78.5^{\mathrm{d}}(\mathrm{C}-5), 62.8^{\mathrm{e}}(\mathrm{C}-6) .{ }^{\mathrm{a}-\mathrm{e}}$ は入れ替わり得る.

以上の結果より，“Tomorrow’s Snowy Night’の花弁から 精製された黄色色素は chalcononaringenin 2',4'-diglucoside であることが明らかになった。

\section{4. 黄色変異体の色素蓄積および花糸における色素蓄積の 解析}

‘Tomorrow’s Snowy Night’ の黄色変異体では，親個体と 比較して, HPLC 全ピーク面積が約 1.6 倍に増加しており (第 4 図 A), chalcononaringenin 2',4'-diglucoside の ピーク 面積は約 8 倍に増加していた（第 4 図 B). chalcononaringenin 2',4'-diglucosideのピークを除いた全ピーク面積も親 個体の約 1.4 倍であったため (データ略), 黄色変異体で は色素量が全体的に増加していると考えられたが，なかで も chalcononaringenin $2^{\prime}, 4^{\prime}$-diglucoside 蓄積量のみが顕著に 増加していると考えられた。 また, ピンク品種“タミレス” の花弁からは chalcononaringenin 2',4'-diglucoside は検出さ れなかった（第 4 図 B). 花糸抽出液の HPLC 分析の結果, 花糸では chalcononaringenin $2^{\prime}, 4^{\prime}$-diglucoside のピーク面積 が最も大きく，主要色素であった（データ略）。黄色変異 体では，花糸に拉いても親個体と比較して全ピーク面積が 増加していたが（第 4 図 C), 黄色色素ピーク面積は全ピー ク面積の増加に伴い増加して扣り，特異的に増加している わけではなかった（第 4 図 D)。また，花弁では蓄積のみ られなかった‘タミレス’に拈いても花系では黄色色素の ピークが検出された（第 4 図）。よって, ‘Tomorrow’s Snowy Night' の花弁に蓄積する黄色色素は花系に蓄積す る黄色色素と同一であり, 花糸に掠いては他品種でも蓄積 していることが明らかになった。

\section{考察 \\ 1. セントポーリアの黄色色素}

本研究でセントポーリア ‘Tomorrow's Snowy Night' の 花弁基部に蓄積する黄色色素として chalcononaringenin 2',4'-diglucoside が同定された. chalcononaringenin 2',4'-diglucoside はカンアオイ属 (Asarum) およびタカアシ サイシン (Saruma henryi）の葉に蓄積していることが報告 されているが (Iwashina・Kitajima, 2000; Iwashina ら，2002, 2005)，花弁での蓄積はセントポーリアを用いた本誌が初 めての報告である。 ‘Tomorrow’s Snowy Night' 以外の黄色 品種でも chalcononaringenin 2',4'-diglucoside が検出された ことから (データ略), 現在流通しているセントポーリア の黄色品種はこの色素により黄色を呈していると考えら れた。

2. chalcononaringenin $2^{\prime}, 4^{\prime}$-diglucoside の合成機構 アサガオおよびカーネーション (Dianthus caryophyllus
L.）の花弁に蓄積する黄色色素 chalcononaringenin(chalcone) 2'-glucoside は，アントシアニン合成経路上のカルコン 異性化酵素（CHI）の機能欠損により合成されることが 報告されている（Forkmann・Dangelmayr, 1980; Itohら， 2002; Saito ら，2011）。 たたこの黄色色素の合成にはカ ルコンへのグルコース転移酵素（CHGT）のはたらきが重 要であることも示唆されている（Itoh ら，2002）。って, セントポーリア ‘Tomorrow’s Snowy Night' の花弁基部で の chalcononaringenin $2^{\prime}, 4^{\prime}$-diglucoside の蓄積にはCHI およ び $C H G T$ の発現が関与している可能性があり，今後はこ れらの遺伝子発現を中心に解析を進めていくことになる. また，この黄色色素は，花弁には本色素を蓄積しないピン ク品種 ‘タミレス’の花系でも検出されたため，花糸に拉 いては一般的に蓄積する色素であることが示唆された. 従って，黄色品種だけでなくその他の花色を示す品種も広 $く$ chalcononaringenin $2^{\prime}, 4^{\prime}$-diglucoside 合成能力を有してい る可能性が示唆された.

\section{3. 'Tomorrow's Snowy Night' の黄色変異体}

組織培養で得られた ‘Tomorrow’s Snowy Night’の黄色 変異体は, 花弁全体での全色素量が親個体と比較して増加 して扣り（第 4 図A），特に黄色色素 chalcononaringenin 2',4'-diglucoside の蓄積量が著しく増加していた（第 4 困 B). 花弁基部での黄色色素蓄積量を親個体と比較すると 1.5 倍程度であったことから (データ略), 黄色変異体にお ける花弁全体での黄色色素蓄積量の大幅な増加は, 見た目 に明らかなように花弁上の蓄積部位の拡大の結果であると 考えられた。すなおち，黄色変異体では黄色色素合成が花 弁の大部分で生じるよらな変異が起こっていると考觉られ た. 今回，セントポーリアの黄色色素が chalcononaringenin 2',4'-diglucoside であることが明らかになったことか ら，今後，合成遺伝子の特定や部位特異的な着色機構の解 明といった進展が期待できる.

\begin{tabular}{|c|}
\hline 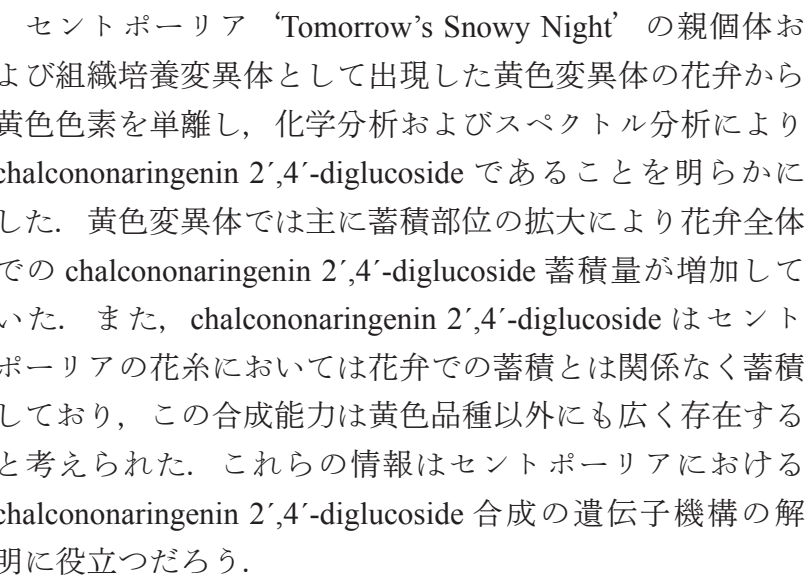 \\
\hline
\end{tabular}

\section{引用文献}

Deguchi, A., F. Tatsuzawa, M. Hosokawa, M. Doi and S. Ohno. 
2015. Tobacco streak virus (strain dahlia) suppresses posttranscriptional gene silencing of flavone synthase II in black dahlia cultivars and causes a drastic flower color change. Planta. 242: 663-675.

Forkmann, G. and B. Dangelmayr. 1980. Genetic control of chalcone isomerase activity in flowers of Dianthus caryophyllus. Biochem. Genet. 18: 519-527.

Griesbach, R. J. 1998. Flavonoids in Saintpaulia ionantha expressing the fantasy mutation. Phytochemistry 48: 829-830.

Harborne, J. B. 1966. Comparative biochemistry of flavonoidsII.: 3-Desoxyanthocyanins and their systematic distribution in ferns and gesnerads. Phytochemistry 5: 589-600.

Harborne, J. B. 1984. Phytochemical methods, second ed. Chapman and Hall, London and New York.

Itoh, Y., D. Higeta, A. Suzuki, H. Yoshida and Y. Ozeki. 2002. Excision of transposable elements from the chalcone isomerase and dihydroflavonol 4-reductase genes may contribute to the variegation of the yellow-flowered carnation (Dianthus caryophyllus). Plant Cell Physiol. 43: 578-585.

Iwashina, T. and J. Kitajima. 2000. Chalcone and flavonol glycosides from Asarum canadense (Aristolochiaceae). Phytochemistry 55: 971-974.

Iwashina, T., J. Kitajima, T. Shiuchi and Y. Itou. 2005. Chalcones and other flavonoids from Asarum sensu lato (Aristolochiaceae). Biochem. Syst. Ecol. 33: 571-584.
Iwashina, T., W. Marubashi and T. Suzuki. 2002. Chalcones and flavonols from the Chinese species, Saruma henryi (Aristolochiaceae). Biochem. Syst. Ecol. 30: 1101-1103.

Khokhar, J., J. Humphreys, K. Short and B. Grout. 1982. Anthocyanins in African Violet. HortScience 17: 810-811.

Murashige, T. and F. Skoog. 1962. A revised medium for rapid growth and bioassay with tobacco tissue culture. Physiol. Plant. 15: 473-497.

Saito, N., F. Tatsuzawa, A. Hoshino, Y. Abe, M. Ichimura, M. Yokoi, K. Toki, Y. Morita, S. Iida and T. Honda. 2011. Anthocyanin pigmentation controlled by speckled and $c-1$ mutations of Japanese morning glory. J. Japan. Soc. Hort. Sci. 80: 452-460.

Tatsuzawa, F. and M. Hosokawa. 2016. Flower colora and their anthocyanins in Saintpaulia cultivars (Gesneriaceae). Hort. $\mathrm{J}$. , in press.

Tatsuzawa, F., M. Hosokawa, N. Saito and T. Honda. 2012. Three acylated anthocyanins and a flavone glycoside in violet-blue flowers of Saintpaulia 'Thamires'. S. Afr. J. Bot. 79: 71-76.

Tatsuzawa, F., S. Matsuda, K. Kato and M. Hosokawa. 2015. Acetylated anthocyanidin 3-O-di-glycosides in red-purple flowers and grayed-purple leaves of Saintpaulia 'Tomoko'. Hort. J. 84: 77-82. 